\title{
The Economic Impact of Investment in Renewables in Croatia by 2030
}

\author{
Tomislav Gelo, Nika Šimurina (1) and Jurica Šimurina * (1) \\ Faculty of Economics and Business, University of Zagreb, HR-10000 Zagreb, Croatia; tgelo@net.efzg.hr (T.G.); \\ nsimurina@efzg.hr (N.Š.) \\ * Correspondence: jsimurina@efzg.hr
}

Citation: Gelo, T.; Šimurina, N.; Šimurina, J. The Economic Impact of Investment in Renewables in Croatia by 2030. Energies 2021, 14, 8215 . https://doi.org/10.3390/en14248215

Academic Editors:

Katarzyna Bilińska-Reformat,

Vincenzo Bianco, Donato Morea and Edmundas Kazimieras Zavadskas

Received: 11 October 2021

Accepted: 3 December 2021

Published: 7 December 2021

Publisher's Note: MDPI stays neutral with regard to jurisdictional claims in published maps and institutional affiliations.

Copyright: (c) 2021 by the authors. Licensee MDPI, Basel, Switzerland. This article is an open access article distributed under the terms and conditions of the Creative Commons Attribution (CC BY) license (https:/ / creativecommons.org/licenses/by/ $4.0 /)$.

\begin{abstract}
At the beginning of 2020, the Strategy of the Republic of Croatia until 2030 with an outlook to 2050 was adopted. The Strategy analyzes two energy transition scenarios, the accelerated energy transition and the moderate energy transition. The Strategy is guided and defined by goals set out by the European Union (EU), which primarily states to decrease greenhouse gas emissions and increase the share of renewable energy sources. In order to reach these goals, it is necessary to substitute fossil fuel capacities with new capacities for the production of electricity from renewable sources. In order to do so, a new wave of investments is needed. The Strategy does not detail the macroeconomic effects of investments in renewable sources on the Croatian economy, generally quantified through GDP growth and employment. This paper analyzes the macroeconomic effects of announced investments in renewable energy sources for electricity production. The analysis encompasses the time period 2021-2030. The effects are quantified using the input-output tables for Croatia. The analysis exhibits relatively modest macroeconomic effects of investments into renewable energy on the Croatian economy. The paper concludes that it is necessary to change the structure and dynamics of investment in renewable energy. First, the investment should go into sources with the highest domestic component in investments and at the same time develop production capacities in technologies and equipment production for wind and solar capacities.
\end{abstract}

Keywords: input-output analysis; energy strategy; renewables; energy transition

\section{Introduction}

Consumption of fossil fuels harms the environment and is the leading cause of climate change. This fact influenced energy to become one of the essential areas of common interest to all EU member states within the common energy and climate policies. Today, the EU, guided by the common energy policy, leads the process of decarbonizing economic activity and focuses on transformation toward a low carbon economy according to the Paris Accords. All member states are following the common energy and climate policies by achieving the set goals. After the 2020 goals were met, 2030 goals were defined. Two primary goals are connected to renewable energy sources (RES): decrease greenhouse gasses by $40 \%$ until 2030, compared to 1990, and increase the share of renewable energy sources in energy consumption to $32 \%$ [1]. According to the established goals, each member state creates a national development strategy for ten years. The long-term energy development goals defined by the energy strategy should not be an expression of current wishes but sourced to available options and means of realization.

The EU climate goals, besides environmental impact, have a profound economic impact on respective EU member states. The impact is not uniformly distributed among countries. The economic effects can be stronger or weaker depending on the structure of economic activity, innovation, and the scope of innovations. If innovation implementation is proper, it can create a strong position in the market. In order to create a favorable market position, countries should engage in digitalization and Industry 4.0 solutions to influence 
the development of companies and achieve results concerning sustainable development and environmental impact [2].

Besides achieving defined energy and climate goals, it is necessary to maximize macroeconomic effects on the economy, and the Croatian economy is currently ranked 26th out of 27 member states. The rank is primarily true for the growth of GDP and gross value added. General macroeconomic data shows the average growth rate 2015-2019 was 3\%, GDP in 2019 was 53 billion EUR, the employment rate was $48 \%$, and unemployment was $6.6 \%$. Key indicator of macroeconomic effects is the growth of employment, both total and according to respective sectors of the economy. Improvement in employment is possible if renewables are based on skills and equipment sourced in Croatia (e.g., hydropower amounts to $90-95 \%$ of domestic contribution in Croatia). Some facilities for the production of electricity from renewable sources, in most part or entirely, are imported (solar and wind plants). Maximization of macroeconomic effects in Croatia could be reached by using remaining hydro potential first, primarily hydropower (and other facilities produced in Croatia), and only after investment more into the wind and solar plants. The reason is the expected decrease of investment costs for solar, wind, and other renewable facilities in time.

The capacity of renewables in Croatia in 2020 was 1060 MW. The largest portion was in the wind, with almost $70 \%$ of the total capacity. The next largest share is in cogeneration and biomass power plants with a $10 \%$ share. Solar and biogas plants take $5 \%$ each. Around $1 \%$ is from landfill gas. The trend is expected to follow the current pattern in the next decade, given the energy and climate policies of the EU [3].

As suggested by Uzar [4], besides macroeconomic and environmental determinants of renewable energy, political and institutional factors are important, where it is concluded that institutional quality positively affects renewable energy consumption in the long run. In addition, an interesting point is raised from the point of a respective sector (agriculture) by Eyuboglu and Uzar [5], where they conclude that economic growth and energy consumption enhance $\mathrm{CO}_{2}$ emissions and trade openness decreases it.

This paper aims to connect national energy strategy, the EU energy strategy goals, and national performance. We argue that the mix of investments into renewables does not yield identical or even similar results among countries. Thus, the aims of the Croatian Strategy should be guided by maximizing growth from investments in renewables and not only by environmental goals. The main research question that stems from the aim of the paper is: how do set goals in Croatia (environmental and energy scenarios) of the Energy Strategy influence main macroeconomic variables?

The contribution of this paper is quantification of macroeconomic effects in a small EU member state (Croatia) that carries idiosyncrasies given economic, environmental and energy structure. For this purpose, we used input-output analysis based on the Croatian input-output tables for 2015 and respective investment scenarios in the Croatian Energy Strategy. The policymakers should consider the conclusions of this paper when deciding on the time dynamics of respective investments into renewables and on respective renewable's economic impact in both the short and long run.

\section{Literature Review}

Research at the EU level suggests positive effects of investments in renewables, i.e., the transformation from fossil fuels to renewable energy sources. The European Commission [6] estimated, in 2014, renewable energy sources in the EU to generate an additional 1.25 million jobs. Impact on GDP, given the analyzed scenarios, will be less than $1 \%$.

It is estimated that the total net effect on employment will be 530,000 jobs with spillovers among countries taken into account (e.g., employment created in one country due to changes in another country) [7].

Research on the EU and the United States provide different results given the potential of national industries to produce technology for renewable sources. Bulavskaya and 
Frédéric [8] analyze the economic impact of the transition to renewable sources in the Netherlands. They conclude that the transition to renewable sources might positively influence the Dutch economy, creating almost 50,000 new jobs by 2030 and adding almost $1 \%$ to GDP. Garrett-Peltier [9] stresses investing in clean energy to create three jobs for every lost job in fossil fuel activities. Additionally, for every transition from fossil fuels to clean energy in the amount of one million US dollars, on average, five additional jobs are being created. It is important to stress that the mentioned research is focused on the short-run decrease of fossil fuels production on employment with an increase in clean energy production. Research in Greece [10] suggests that needed investment into renewable sources for 2010-2020 would amount to EUR 47.9 billion. The investments would result in an annual average GDP increase of EUR 9.4 billion, creating at the same time 108,000 fulltime equivalent jobs for the entire observed period. The analysis of renewables in the Czech Republic [11] for 2008-2013 shows more than 20,000 jobs created only in 2010 due to investment into renewables. The research further exhibits the strong dependence of new jobs created on the continuation of financial incentives by the government. Biomass and biogas energy conversion offer the highest employability per MWh, suitable for employment in (economically sensitive) rural areas.

Research on the influence of renewables on GDP and employment in the US yields positive results, same as in the EU Research performed for the state of Nebraska [12] encompasses direct, indirect, and induced effects of wind power plants on employment. Development, construction, and operations of the wind power plants of the total capacity of 7800 MW through 40 years have an average impact of 1600-2925 full-time equivalent new jobs. The research on twelve US states, so-called wind regions of the US, was performed from 2000-2008. The analyzed area marked a total GDP increase of around USD 11,000 per MW and job growth of 0.5 per MW of installed capacity in the wind for the observed period [13]. At the level of the world, the analysis shows that doubling the share of renewables in the world energy mix by 2030 would increase GDP between 0.7 and $1.1 \%$, or USD 700-1300 billion. Should the doubling of renewables share be achieved through the higher velocity of electrification, the global GDP increase would be even higher [14]. There are only several published papers in Croatia on the influence of installed capacity of renewables for electricity production. In the first all-encompassing work on Croatia [15] published in 2018, for the first time, the economic impact of investment into renewables is quantified. The biogas plants create the highest total direct and indirect effects on GDP for EUR 454,000 (based on total investment value of EUR 1 million). If we add induced effects, we obtain the total effect of investment in biogas plants on GDP of EUR 674,000. At the same time, the same investments create 18-27 (with induced effects) jobs. Almost identical economic effects on GDP and employment are recorded for small hydro plants, and 5-10\% smaller effects are induced by solar plants. The effect of biomass, direct and indirect, on GDP is around EUR 395,000 and 595,000 with induced effects included. The effect on employment is 15-25 (with induced effects) new jobs created. The smallest effects are detected for wind power plants which have the largest share of renewables in Croatia. Direct and indirect effects on GDP amount to EUR 224,000 and 344,000 (with induced effects). The effect on employment is around 9 and 14 (with induced effects) new jobs created. Low multiplier effects of wind power stem from the low share of Croatian suppliers in total investment. The most prominent economic effects in the structure of the Croatian economy are created in the manufacturing industry, followed by construction, and finally, services. Mikulic et al. [16] quantified the total effects of wind power on the Croatian economy by their influence on employment and gross value added. They came to identical conclusions. Incentives policy for renewables in Croatia could have larger effects if energy and industry strategies are better aligned [17].

\section{Data}

The Croatian parliament accepted the Energy Strategy in 2020 [18] (N.N. 25/2020). The Strategy is aimed at goals defined by the EU, namely: decrease of greenhouse gas 
emissions, increase of the share of renewables, an increase of energy efficiency, security and quality of supply, development of the EU energy market, energy infrastructure, and competitive economy and the energy sector. The Strategy analyzes two energy transition scenarios, scenario 1 (S1-accelerated energy transition) and scenario 2 (S2-moderate energy transition). According to S1, decarbonization of electricity production aims to increase the share of renewables to $66 \%$, and according to the S2, to $61 \%$ until 2030 . According to both scenarios, the share of renewables in total energy consumption is set to $32 \%$. Scenarios encompass 12 activities where investments are considered in order to reach the goal. Electricity production is one of 12 activities analyzed for both scenarios in the Strategy. This paper focuses on the macroeconomic effects of investments in the production of electricity only. Table 1 exhibits the production structure of electricity given the defined scenarios [19].

Table 1. Expected electricity production and its structure according to the production technology for S1 and S2 scenarios.

\begin{tabular}{|c|c|c|c|c|c|c|c|c|}
\hline in GWh & 2017 (P) You & Share & S1 & Share & Change & S2 & Share & Change \\
\hline Production Technology & 2017 (Dase Year) & $\%$ & 2030 & $\%$ & $2030 / 2017$ & 2030 & $\%$ & $2030 / 2017$ \\
\hline Industrial cogeneration & 414 & 3 & 320 & 2 & $77 \%$ & 320 & 2 & $77 \%$ \\
\hline Public cogeneration & 3383 & 28 & 3316 & 19 & $98 \%$ & 3508 & 21 & $104 \%$ \\
\hline Thermal plants & 1397 & 12 & 720 & 4 & $52 \%$ & 800 & 5 & $57 \%$ \\
\hline Geothermal plants & 0 & 0 & 129 & 1 & - & 129 & 1 & - \\
\hline Solar plants & 79 & 1 & 1371 & 8 & $1742 \%$ & 1013 & 6 & $1288 \%$ \\
\hline Wind plants & 1204 & 10 & 4332 & 25 & $360 \%$ & 3549 & 21 & $295 \%$ \\
\hline Hydro plants & 5508 & 46 & 7307 & 42 & $133 \%$ & 7319 & 44 & $133 \%$ \\
\hline TOTAL & 11,985 & 100 & 17,495 & 100 & $146 \%$ & 16,638 & 100 & $139 \%$ \\
\hline
\end{tabular}

Within the energy transition framework, renewables are expected to increase along with the greater diversification of energy sources. In S1 until 2030, the use of renewables would increase to $42 \%$, while in S2, it goes to $49 \%$. The most significant changes are in considerable increases of the share of wind and solar. Electricity production from wind and solar should increase from 1.3 TWh in 2017 to 5.7 TWh in 2030 in S1 and 4.6 TWh in 2030 in S2. The share of wind and solar should grow from $11 \%$ in 2017 to 33\% in 2030 in S1, and $27 \%$ according to S2. In order to achieve these projections, considerable investments are needed in renewables. Table 2 shows investment in electricity production and its structure according to technology and scenario for the period 2021-2030 [19].

Table 2. Investment in production of electricity according to S1 and S2, 2021-2030.

\begin{tabular}{lcccc}
\hline \multicolumn{1}{c}{ Billion EUR } & \multicolumn{2}{c}{ 2021-2030 } \\
\hline \multicolumn{1}{c}{ Production Capacity } & S1 & \% & S2 & \% \\
\hline Wind & 0.84 & 32.9 & 0.67 & 30.7 \\
\hline Solar & 0.68 & 26.8 & 0.54 & 24.7 \\
\hline Hydro & 0.58 & 22.6 & 0.51 & 23.5 \\
\hline Gas & 0.3 & 11.8 & 0.03 & 13.3 \\
\hline Biomass & 0.12 & 4.8 & 0.13 & 5.9 \\
\hline Energy storage & 0.007 & 03 & 0.015 & 0.7 \\
\hline Geothermal & 0.012 & 0.5 & 0.02 & 0.9 \\
\hline Heat pumps and electric boilers & 0.008 & 0.3 & 0.01 & 0.4 \\
\hline \multicolumn{1}{c}{ TOTAL } & 2.55 & 100.0 & 2.18 & 100.0 \\
\hline
\end{tabular}


According to S1, total expected investments amount to EUR 2.55 billion in the ten-year period, which means annually on average EUR 0.25 billion. That amount of $11 \%$ of expected investments in all 12 activities for energy transition for the period 2021-2030 amounted to EUR 22.5 billion (around EUR 2.25 billion annually). The greatest share goes towards investment in the refurbishment of old or construction of new buildings (44\%). Investment in solar and wind plants is scheduled at $60 \%$ of investments in renewables, which is EUR 0.15 billion. The hydro potential is in third place, followed by gas power plants. Gas plants are not a renewable source but are necessary given their flexibility in the power system with many renewables. In the S2 case, $15 \%$ less investment is scheduled for 2.18 billion EUR in the ten years (EUR 0.22 billion annually). This amounts to $11.5 \%$ of total scheduled investment in 12 activities which amounts to EUR 18.86 billion (EUR 1.93 billion annually). The share in this scenario is led by investment into wind and solar plants, which amount to $55 \%$ or EUR 1.2 billion. It is assumed that the investment in both scenarios is linearly distributed in the ten years.

In order to estimate the macroeconomic effects of analyzed scenarios, investments are disaggregated into individual areas according to investment products or services necessary to procure in the domestic economy and/or trade partners. Disaggregation assumes that, in the analyzed period 2021-2030, the investment would go in the following groups of products and services:

- C28-Machinery and equipment (33\%);

- C27-Electrical equipment (31\%);

- F-Constructions and construction works (20\%);

- C33-Repair and installation services of machinery and equipment (12\%);

- $\quad$ C24-Basic metals (2\%);

- J62-J63-Computer programming, consultancy, and related services; information services (1\%);

- K65-Insurance, reinsurance, and pension funding services, except compulsory social security $(1 \%)$.

Disaggregation of investment is performed according to the Statistical Classification of Economic Activities for Croatia in 2015.

\section{Methodology}

Here, we use input-output analysis, a practical and commonly used macroeconomic analysis tool where we can test and determine relations among all production sectors of a national economy. Wassily Leontifes is considered a founder of the input-output analysis (IOA), and it was first implemented for the US in 1919 and 1929 [20], which is considered the start of the modern input-output analysis. Although today's input-output analysis has moved forward in its theoretical and applied considerations, the basic model remained almost the same as the original. There are numerous published works on the input-output analysis from its conception until today [21-25]. Applied and theoretically, IOA is considerably more developed than in its beginnings. One of its features is applied in energy analysis, especially after the Oil Shocks in the 1970s [26-28] and after [29-31]. An important application is in environmental studies, which are closely connected to energy consumption and greenhouse gasses. Today, it is commonly used to analyze the macroeconomic effects of an investment in electricity production from renewables such as wind, hydro, solar, and other renewable technologies.

The basic structure of the input-output model [25,32-35] represents, in a static manner, structural relationships between domestic production sectors of a national economy. As mentioned above, input-output analysis is developed by Leontief, assumes stability of technical coefficients, and uses matrix algebra for estimation of direct and indirect effects. Besides the national economy, input-output analysis encompasses exchange of goods and services with other economies and thus identifies supply chains at the domestic and international levels. 
Assumptions, procedures, techniques, and applications of an input-output analysis can be found closely depicted in Ten Raa [33] and Miller and Blair [25]. Technically, the economy is described through sectors that produce goods and services. An important segment of the input-output model is that the total output of a particular sector is equal to the sum of the intermediate inputs and gross value added. Mathematical operations and transformations, described by Miller and Blair [25], are presented below.

$$
\begin{gathered}
x_{i}=\sum_{j=1}^{n} x_{i j}+C_{i}^{D}+G_{i}^{D}+I_{i}^{D}+E_{i}^{D} \\
A^{D} x+y^{D}=x \\
x=\left(I-A^{D}\right)^{-1} y^{D}
\end{gathered}
$$

where in (1), $x_{i}$ denotes the output of sector $i, x_{i j}$ represents the output of sector $i$ delivered to sector $j$ as an intermediate input. The output of sector $i$ is equal to deliveries to other sectors and final users. Demand is the sum of consumption $(C)$, government spending $(G)$, investment $(I)$, exports $(E)$, and superscript $D$ denotes the domestic producer. The assumption of the analysis is constant technical coefficient describing inter-sectoral connections ( $a_{i j}^{D}$ for domestic and $a_{j}^{U}$ for import content). If we describe elements in row $i$ and column $j$ as $a_{i j}^{D}$ in a matrix $A^{D}$, in order to produce at the level $x$, domestic intermediates required are described as $A^{D} \times x$. If we describe the demand for domestic products $y^{D}=C^{D}+G^{D}+I^{D}+E^{D}$, we obtain that the output is as described by (2). From (2) with several mathematical operations, the transformed equation is (3). In (3) $x$ describes the level of production needed to satisfy the growth of exogenous demand given in the form of vector $y^{D}$ The case of investments envisioned by the Strategy represents the expected total annual investment according to the respective scenarios. It is distributed according to groupings of products and services, where products and services, in which it is invested, belong to. Multiplier effects of planned investments are calculated according to the matrix $\left(I-A^{D}\right)^{-1}$, also called the Leontief multiplier matrix. The given model can calculate macroeconomic effects of planned investment according to the Energy Strategy on macroeconomic variables, e.g., value added, employment, imports, GDP.

Macroeconomic effects are calculated using input-output analysis based on the inputoutput tables for Croatia from 2015, published in 2019 [35]. The analysis considers direct and indirect (multiplicative) effects of investments disaggregated using different estimates to specific fields (out of 65 fields) contained in a symmetric input-output table given the specific aspects of every investment. The direct effects encompass additional employment, thus income, in sectors that produce goods and services for additional final demand. Indirect effects encompass indirect employment, thus income, of other sectors that increase production to supply intermediary inputs necessary for production in sectors directly involved in the supply of output needed for final demand. The input-output model encompasses existing technological connections among 65 existing sectors of the Croatian economy. The ratio of imported and domestic components is based on individual sectors of the input-output table for 2015.

The key advantage of the input-output model includes the possibility of estimating effects at a relatively high level of disaggregation. Thus, the total economic effects of change in demand for specific products and services can be quantified. In addition, it offers a possibility to analyze interdependence among different sectors given the use of information on groups of sectoral relations which describe changes in employment, output, or income of industry given the changes in demand in another industry. The fundamental limitation of the input-output is its static nature. Multipliers derived from the input-output model represent only a snapshot of an economy in a given moment or year. Given its static nature, it is assumed that prices are fixed, and it does not consider the possibility of factor substitution or changes in competitiveness or other demographic effects that occur in the long run. The absence of resource limitations, substitution effect, and replacement (time 
duration of a project) with time indicate that the input-output models tend to overestimate policy effects on employment [36].

\section{Results}

Given the input-output table for 2015, expected investments, their linear annual distribution, and estimated disaggregation by sector, we have completed the input-output analysis and calculated sectoral and macroeconomic effects of investments in electricity production from renewables for the period 2021-2030, according to the Energy Strategy of the Republic of Croatia. The total absolute annual effects of the input-output analysis are depicted in Table 3.

Table 3. Total absolute annual effect of investment for the period 2021-2030 (million EUR).

\begin{tabular}{ccccccc}
\hline Scenario & Investment & Employment & Value Added & Imports & Taxes & GDP \\
\hline S1 & 255.9 & 3549 & 86 & 164.5 & 20 & 106 \\
\hline S2 & 217.6 & 3046 & 73.7 & 140.1 & 17.2 & 91.9 \\
\hline
\end{tabular}

S1 estimates annual investments of EUR 255.9 million, value added of EUR 86 million, imports of EUR 164.5 million, taxes of EUR 20 million, and GDP growth by EUR 106 million. Employment would increase annually by 3500. In S2, with estimated investments of EUR 217.6 million, value added would increase by EUR 73.7 million imports by EUR 140.1 million, taxes by EUR 17.2 million and GDP would grow by EUR 91.9 million. Employment would increase by 3000. It can be expected that employment growth would not have identical dynamics through the observed period due to labor productivity, new technologies, transfer of labor from finished to new projects, etc.

The analysis shows that EUR 1 million investment in production capacities for electricity production from renewables, according to both S1 and S2, creates approximately EUR 0.336 million of value added. With the addition of EUR 0.078 million of tax revenues, it amounts to EUR 0.414 million of GDP increase. Out of the increase of GDP, $45 \%$ would be created in the industry, $31 \%$ in services, and $24 \%$ in construction. At the same time, it is necessary to increase imports by HRK 643 million. Investment of EUR 1 million creates approximately 14 jobs, $46 \%$ in industry, $32 \%$ in construction, and $22 \%$ in services.

\section{Discussion}

In Croatia, it is customary for energy strategy creation to be rooted in climate goals and associated energy policy for achieving these goals. Economic effects are considered secondary or utterly missing from the analysis. Given the fact that Croatia resides in 26th place out of $27 \mathrm{EU}$ member states according to economic development, economic goals should at least be at the same level as the climate goals, if not even more critical, given the negligible influence of Croatia on climate change $(0.07 \%$ of total).

This analysis aimed to estimate the macroeconomic effects of an investment in electricity production according to the approved and accepted Energy Strategy of the Republic of Croatia [18]. The foundation for an estimate of macroeconomic effects is "Estimates of total investment in the period 2021-2030" (in Croatian "Procjena ukupnih ulaganja u razdoblju od 2021. do 2030. Godine") analyzed in the "Green Book" [19]. For estimates of effects, we used energy scenarios of the moderate and accelerated energy transition.

Conducted input-output analysis and associated results point to weak macroeconomic effects of an investment in renewables in the period 2021-2030 according to the Energy Strategy of the Republic of Croatia for the Croatian economy. The results are shown through GDP and employment, both total and by sector. We estimate that for every EUR 1 million of investment in capacities for electricity production from renewables, the Croatian economy creates, directly and indirectly, only EUR 0.336 million of value added and EUR 0.410 million of GDP. Investment in renewables significantly increases imports which is 
more than double of newly created GDP. At the same time, EUR 1 million investment creates 14 new jobs, $46 \%$ in industry, $32 \%$ in construction, and $22 \%$ in services.

Given the results presented here, and data from previous studies on Croatia (e.g., Mikulić [16]), we can conclude that our estimates are expectedly lower because we did not include induced effects and we used the average of all renewables investment, and the previous studies included the separate investment of each respective renewable's on macroeconomic variables. Thus, our results show the impact of 14 new jobs created per EUR 1 million investment, while other studies show the range of 15-27 jobs created, with the highest impact of bioenergy in the range.

According to everything said above, conclusions point to the significant under-capacity of the Croatian industry to manufacture equipment for electricity production from renewables. The ratio is $40 \%$ new value creation to $60 \%$ imports. This is especially true for wind power equipment (Croatia does not produce wind generators) and solar plants, $55-60 \%$ of total investment into renewables. Conversely, hydropower plants can be constructed using almost $100 \%$ of products of the Croatian industry (Croatia produces turbines, generators, and transformers); however, they make only $22 \%$ of total investment. The production capacity of hydropower in Croatia is at $50 \%$ of the total installed capacity. However, there is room to extend the hydro capacity on rivers Sava and Drava in the North of Croatia, and there is also spare capacity in hydropower plant Dubrovnik where two more aggregates can be added (roughly $250 \mathrm{MW}$ ).

We conclude that the economic effects would be more significant if the structure and dynamics of investments in renewables could be altered. Larger investments in the first years should go toward renewables with a high domestic component (e.g., hydro). With new domestic capacity, investment in wind and solar should be pushed toward the end of the investment period. At the same time, it is necessary to accelerate industrial growth through the development of manufacturing capacities of technologies and equipment for wind and solar plants, independently or in cooperation with international partners. Wojdalski et al. [37] showed that there is a possibility of increasing energy production efficiency based on the introduction of technological innovation.

The research results align with similar research conducted thus far on the influence of respective renewables on GDP and employment. According to the research conducted in the EU and the World, Croatia is among countries that have a relatively modest impact of investments in renewables on economic indicators. Furthermore, renewables with the most negligible impact dominate the structure of existing capacity (wind) and are the foundation for the future capacity expansion according to the Energy Strategy.

Long-run projections should be taken with caution. The conducted analysis is limited by availability and the quality of data, primarily due to the distribution of total investments according to sectors of the Croatian economy and ratios of import and domestic components according to the sector in the 2015 input-output tables. The input-output analysis is static, and it does not take future changes into account. Thus, it does not consider future changes in technological connections and prices among different activities and factors, and does not allow substitution of production factors, nor does it employ potential resource limitation. In addition, this analysis does not encompass induced effects, including induced employment and thus created income by producers of goods and services aimed at household consumption.

Future input-output analysis-based research should account for, besides direct and indirect effects, the induced effects of investment. $\mathrm{n} \mathrm{I}$, it is necessary to widen analysis with effects to the national economy through demand channels for intermediary goods and services needed for running operations of facilities of renewables during their lifetime. In this way, the total effects of renewables on the Croatian economy could be encompassed.

Author Contributions: Conceptualization, T.G.; methodology, T.G.; validation, N.Š. and J.Š.; formal analysis, T.G.; investigation, J.Š.; resources, N.Š.; data curation, T.G.; writing-original draft preparation, T.G.; writing-review and editing, J.Š.; visualization, T.G.; supervision, N.Š.; project 
administration, N.Š.; funding acquisition, J.Š. All authors have read and agreed to the published version of the manuscript.

Funding: This paper has been fully supported by the Croatian Science Foundation under project HRZZ-2019-04-4500.

Institutional Review Board Statement: Not applicable.

Informed Consent Statement: Not applicable.

Data Availability Statement: Conducted analysis is based on data depicted in the paper and on the following sources: 1 . Symmetric input-output table at basic prices (product by product) for 2015, Eurostat (link: https:/ / ec.europa.eu/eurostat/databrowser/view/naio_10_cp1700/default/table? lang=en), 2. Green Book-Zelena knjiga-Analiza i podloge za izradu strategije energetskog razvoja Republike Hrvatske do 2030. godine s pogledom na 2050. godinu, Energetski institut Hrvoje Požar, 2019 (link: https:/ / mingor.gov.hr/UserDocsImages/UPRAVA\%20ZA\%20ENERGETIKU/Strategije, \%2 Oplanovi\%20i\%20programi/Analiza\%20i\%20podloga\%20za\%20izradu\%20Strategije\%20energetskog\% 20razvoja\%20Republike\%20Hrvatske\%20-ZELENA\%20KNJIGA\%20_kona\%C4\%8Dna\%20verzija\%20 (002).pdf), 3. Energy Strategy of the Republic of Croatia-Strategija energetskog razvoja Republike Hrvatske do 2030. s pogledom na 2050. godinu (link: https:/ / mingor.gov.hr/UserDocsImages / UPRAVA\%20ZA\%20ENERGETIKU/Strategije,\%20planovi\%20i\%20programi/Strategija\%20energetskog\% 20razvoja\%20RH\%202030\%20s\%20pogledom\%20na\%202050.pdf or link: NN 25/2020: https:/ / narodnenovine.nn.hr/clanci/sluzbeni/2020_03_25_602.html).

Conflicts of Interest: The authors declare no conflict of interest.

\section{References}

1. Revidirana Direktiva o Energetskoj Učinkovitosti i Revidirana Direktiva o Energiji iz Obnovljivih Izvora od 4.12.2018. Available online: https:/ / eur-lex.europa.eu/legal-content/HR/TXT/PDF/?uri=CELEX:32018L2001\&from=LV (accessed on 31 July 2021).

2. Borowski, F.P. Digitalization, Digital Twins, Blokchain, and Industry 4.0 as Elements of Management Process in Enterprise in the Energy Sector. Energies 2021, 14, 1885. [CrossRef]

3. HROTE. Godišnji Izvještaji, Hrvatski Operator Tržišta Energije, Zagreb. 2021. Available online: https://www.hrote.hr/izvjestaji (accessed on 31 July 2021).

4. Uzar, U. Politial economy of renewable energy: Does institutional quality make a difference in renewable consumption? Renew. Energy 2020, 155, 591-603. [CrossRef]

5. Eyuboglu, K.; Uzar, U. Examining the roles of renewable energy consumption and agriculture on $\mathrm{CO}_{2}$ emission in lucky-seven countries. Environ. Sci. Pollut. Res. 2020, 27, 45031-45040. [CrossRef] [PubMed]

6. A Policy Framework for Climate and Energy in the Period from 2020 up to 2030; European Commission: Brussels, Belgium, 2014; Available online: https:/ / eur-lex.europa.eu/legal-content/EN/TXT/PDF/?uri=CELEX:52014SC0015\&from=HR (accessed on 31 July 2021).

7. Markandya, A.; Arto, I.; González-Eguino, M.; Román, M.V. Towards a green energy economy? Tracking the employment effects of low-carbon technologies in the Eu-ropean Union. Appl. Energy 2016, 179, 1342-1350. [CrossRef]

8. Bulavskaya, T.; Reynès, F. Job creation and economic impact of renewable energy in the Netherlands. Renew. Energy 2018, 119, 528-538. [CrossRef]

9. Garrett-Peltier, H. Green versus brown: Comparing the employment impacts of energy efficiency, renewable energy, and fossil fuels using an input-output model. Econ. Modell. 2017, 61, 439-447. [CrossRef]

10. Markaki, M.; Belegri-Roboli, A.; Michaelides, P.; Mirasgedis, S.; Lalas, D.P. The impact of clean energy investments on the Greek economy: An input-output analysis (2010-2020). Energy Policy 2013, 57, 263-275. [CrossRef]

11. Dvořák, P.; Martinát, S.; Van der Horst, D.; Frantál, B.; Turečková, K. Renewable energy investment and job creation; a cross-sectoral assessment for the Czech Republic with reference to E.U. benchmarks. Renew. Sustain. Energy Rev. 2017, 69, 360-368. [CrossRef]

12. Lantz, E. Economic Development Benefits from Wind Power in Nebraska: A Report for the Nebraska Energy Office; Technical Report NREL/TP-500-44344; National Renewable Energy Laboratory: Golden, CO, USA, 2009. Available online: https://www.nrel.gov/ docs / fy09osti / 44344.pdf (accessed on 22 May 2021).

13. Brown, J.P.; Pender, J.; Wiser, R.; Lantz, E.; Hoen, B. Ex post analysis of economic impacts from wind power development in U.S. counties. Energy Econ. 2012, 34, 1743-1754. [CrossRef]

14. IRENA. Renewable Energy Benefits: Measuring The 'Economics'; IRENA: Abu Dhabi, United Arab Emirates, 2016; Available online: https:/ /www.irena.org/-/media/Files/IRENA/Agency/Publication/2016/IRENA_Measuring-the-Economics_2016.pdf (accessed on 31 July 2021).

15. Integralna Analiza Dosadašnjih Učinaka Razvoja i Izgradnje Obnovljivih Izvora Energije u Hrvatskoj u Razdoblju od 2007; Ekonomski institute Zageb i Energetski institute Hrvoje Požar: Zagreb, Croatia, 2018. 
16. Mikulić, D.; Lovrinčević, Ž.; Keček, D. Economic Effects of Wind Power Plant Deployment on the Croatian Economy. Energies 2018, 11, 1881. [CrossRef]

17. Keček, D.; Mikulić, D.; Lovrinčević, Ž. Deployment of renewable energy: Economic effects on the Croatian economy. Energy Policy 2019, 126, 402-410. [CrossRef]

18. Strategija Energetskog Razvoja Republike Hrvatske do 2030. s Pogledom na 2050; Godinu, NN 25/2020, 2020; Hrvatski Sabor: Zagreb, Croatia, 2020; Available online: https://narodne-novine.nn.hr/clanci/sluzbeni/full/2020_03_25_602.html (accessed on 31 July 2021).

19. Analize i Podloge za Izradu Energetske Strategije Republike Hrvatske; Energetski institut Hrvoje Požar: Zagreb, Croatia, 2018; Available online: https://www.hup.hr/EasyEdit/UserFiles/Granske_udruge/CRO\%20industrija/Marija\%20\%C5\%A0utina/ zelena-knjiga.pdf (accessed on 31 July 2021).

20. Leontief, W. The Structure of the American Economy, 1919-1939: An Empirical Application of Equilibrium Analysis; Oxford University Press: Oxford, UK, 1951.

21. Stone, R. Input-Output and National Accounts; Organization for Economic Cooperation and Development: Paris, France, 1961.

22. Miernyk, W. The Elements of Input-Output Analysis; Random House: New York, NY, USA, 1965.

23. Yan, C.-S. Introduction to Input-Output Economics; Holt, Rinehart and Winston: New York, NY, USA, 1969.

24. Richardson, H.W. Input-Output and Regional Economics; JohnWiley and Sons (Halsted Press): NewYork, NY, USA, 1972.

25. Miller, R.E.; Blair, P.D. Input Output Analysis Foundations and Extentions; Prentice Hall: Hoboken, NJ, USA, 2009.

26. Bullard, C.; Herendeen, R. The Energy Costs of Goods and Services. Energy Policy 1975, 1, 268-277. [CrossRef]

27. Griffin, J. Energy Input-Output Modeling; Electric Power Research Institute: Palo Alto, CA, USA, 1976.

28. Blair, P. Hierarchies and Priorities in Regional Energy Planning. Reg. Sci. Urban Econ. 1980, 10, 387-405. [CrossRef]

29. Casler, S.; Wilbur, S. Energy Input-Output Analysis: A Simple Guide. Resour. Energy 1984, 6, 1-15. [CrossRef]

30. Dietzenbacher, E.; Lenzen, M.; Los, B.; Guan, D.; Lahr, L.M.; Sancho, F.; Suh, S.; Yang, C. Input-Output Analysis The Next 25 Years. Econ. Syst. Res. 2013, 25, 369-389. [CrossRef]

31. Eurostat Manual of Supply, Use and Input-Output Tables; European Communities: Luxembourg, 2008.

32. D'Hernoncourt, J.; Cordier, M.; Hadley, D. Input-Output Multipliers Specification Sheet and Supporting Material; Spicoza Project Report; Universite Libre de Bruxelles-CEESE: Brussels, Belgium, 2011; pp. 1-25.

33. Ten Raa, T. The Economics of Input-Output Analysis; Cambridge University Press: Cambridge, UK, 2005. [CrossRef]

34. Leontief, W. Input-Output Economics; Oxford University Press: Oxford, UK, 1986.

35. Eurostat, Symmetric Input-Output Table at Basic Prices (Product by Product) for 2015. Available online: https:/ / ec.europa.eu/ eurostat/databrowser/view / naio_10_cp1700/default/table?lang=en (accessed on 31 July 2021).

36. EPA. Quantifying the Multiple Benefits of Energy Efficiency and Renewable Energy: A Guide for State and Local Governments; U.S. Environmental Protection Agency: Washington, DC, USA, 2018.

37. Wojdalski, J.; Krajnik, M.; Borowski, P.F.; Dróżdż, B.; Kupczyk, A. Energy and water efficiency in the gelatine production plant. AIMS Geosci. 2020, 6, 491-503. [CrossRef] 